\title{
Investigating Students' Needs for Effective English Online Learning During Covid-19 for Polbeng Students
}

\author{
Arita Destianingsih ${ }^{1}$ and Ari Satria ${ }^{2}$ \\ ${ }^{1}$ Politeknik Negeri Bengkalis \\ email: arita@polbeng.ac.id \\ ${ }^{2}$ Politeknik Negeri Bengkalis \\ email: arisatria@polbeng.ac.id
}

\begin{abstract}
The aim of this study is to investigate the students needs for effective English online learning during Covid-19 for State Polytechnic of Bengkalis students. Descriptive survey method was used to find out the target needs and learning needs related to online learning. The data collection used was questionnaire with random samples of 116 students from five different study program. The result of the finding revealed that there were several tools that can be used during online class by considering both students and teachers internet access. The effective tools that can be utilized in explaining the subject and as the virtual tool to replace face to face meeting is Zoom application, while to share and submit the assignment the students preferred Google classroom and WhatsApp. Numerous activities and learning input are also highlighted in order to engage the students to be active in online class. The teachers roles in online class is pointed.
\end{abstract}

Keywords: Online, Learning, and Needs.

\section{INTRODUCTION}

The spread of covid-19 in whole countries in the world has affected all life sectors. Industry, economic, even education has changed dramatically. All routines activities seem to be stopped due to corona virus. This situation makes all Indonesian students' population are not attending school/college. However, to keep all activities running well Indonesia government take decision to have "new normal' system and try to support the continuity of education by utilizing technology while schools/colleges shut down.

ELT- Lectura, Vol 7, No 2, August 2020
Students are required to continue their study from home using online learning system. This is the best solution as keeping the students learn during this crisis. Jena (2020) states that online learning is a learning system by utilizing internet. The teachers have unphysically presence in virtual classroom by creating supporting and comfortable environment for students (Joshua, 2018). Politeknik Negeri Bengkalis has adopted this online learning system since the government announced that the schools and colleges have to be closed. All learning subjects are taught through online learning included teaching and learning English. The teachers and learners use internet to 
communicate virtually during learning processes. There are several tools that have been used during English online learning such as Zoom, Google Classroom, Edmodo, Google Meet, E-mail, WhatsApp. However, to replace the physical meeting with the students, Zoom is one of the effective tools that can be used as virtual face to face meeting. The teachers provide all learning materials that can be accessed by the students in online English learning and create interactive and convenient atmosphere during online class.

Nonetheless, based on the observation during the online class that had been conducted, the students might not attend the class effectively. The students reported that they could not practice and use the target language as well as regular class. They feel more stressful with many tasks given and could not have socialize with friends and just stuck with those assignments. In addition, the condition that most of the students live in different districts in which the accesses of the internet are restricted. This situation makes the students to find the best spot to get better Internet signal. Furthermore, when the teachers are required the students to have English practice in speaking or listening by having videoconference or zoom application, even not all the students might participate since their android smart phone are not supporting. Although the institution gave out free internet data package, this problem might not be solved properly. As Pallof and Pratt in Gudea (2008) state that teaching online isn't always easy, as it calls for guidance and difficult work. It is concluded that instructors should assume to spend extra time in developing the materials and activities, pupil assessment, and other direction related to online teaching.

Therefore, in order to make teaching and learning English more meaningfully during online classes for students of State Polytechnic Bengkalis, this research aim to investigate the students needs to figure out the effective English online learning. One of the solutions to get the profile about what the students' needs, wants, and lack about teaching and learning English online is by conducting needs analysis.

Yalden (2012) states that to evaluate what the students' needs in relation about learning English, a need analysis is very effective to be conducted to achieve this purpose. The analysis of the target needs should be arranged to find out what the students' necessities, wants, and lacks as Nation and Macalister (2010: 25) explain briefly that necessities adjust into required knowledge, lacks describe to present knowledge, and wants accord into subjective needs.

This research is expected to be useful study for English teacher. It would draw the effective way to teach and learn English online during Covid-19 pandemic according to the students' proficiency and fit their necessities, lacks, and wants. English teachers also might prepare what the materials they will teach and what kind of technology they could use during English online teaching and learning.

\section{METHOD}

\subsection{Research Design}

This is descriptive survey study which aims to picture the students needs for effective English online teaching. The investigation about the students needs was carried out by needs analysis using questionnaire, as Berwick in Urun \& Yarar (2015: 2) states that need analysis can be conducted in several different ways which can be categorized as either inductive (case 
studies, observations etc.) or deductive (questionnaires, surveys etc.)

\subsection{Participants}

The participant of this study is the students of State Polytechnic of Bengkalis which is selected randomly about 116 students from five different departments of third semester students.

\subsection{Data Collection Technique}

The data was collected by developing a questionnaire related to students' needs analysis. The questionnaire is consisted of 35 questions. The questionnaire was designed based on the relevant literature to draw what the students' needs, wants, and lack related online teaching. The questionnaire was divided into two parts namely target needs and learning needs. The questions related to the target needs was designed to find out what the learners need to do in target situation, while the learning needs questions was developed to know what the learners need to do to learn (Nation and Macalister, 2010: 24). The questions in the target needs are required the students to answer about their necessities, wants and lacks in learning English while in the learning needs includes the learning input, activities, students' role and teachers' role in learning English online during Corona virus. The questionnaire was distributed via Google form.

\section{FINDING AND DISCUSSION}

\subsection{Result of Students' Needs Investigation}

There were two aspects included in investigating students' needs for effective English online teaching and learning through questionnaire namely target needs and learning needs. Concerning to the students' necessities in learning English, they need to read English descriptive text which was showed in data that $34.9 \%$ of the students need to read descriptive text, while $25.7 \%$ of the students need narrative text and $10.1 \%$ of the students need to read news text. Whereas the topic they suggested to improve their reading skill related to daily activity which was showed from the data $50,9 \%$ of the students chose it, followed by $22.8 \%$ education and $6.1 \%$ health. The other topics they less interested were about politics, hobbies, sport and culture. The result can be seen as the graphic below.

\section{Figure 1: Result of Students’ Needs Investigation}
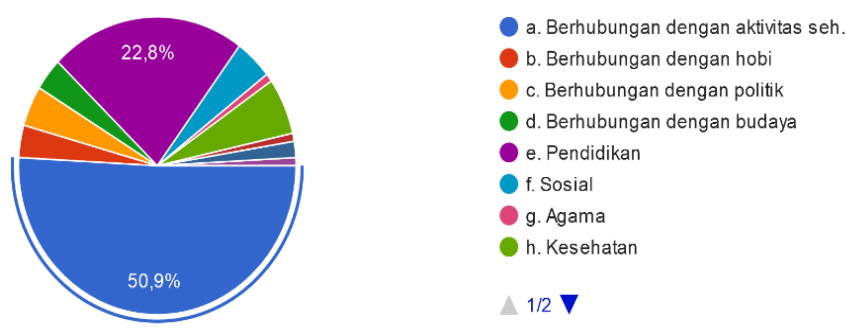

In line with the students' current English proficiency, the data indicates that $64.9 \%$ of the students were in the level beginner, $25.4 \%$ of the students were in intermediate level and 9.6 of the students were in advanced level. The following graphic is briefly described the result of the data.

Figure 2: The Result of the Data
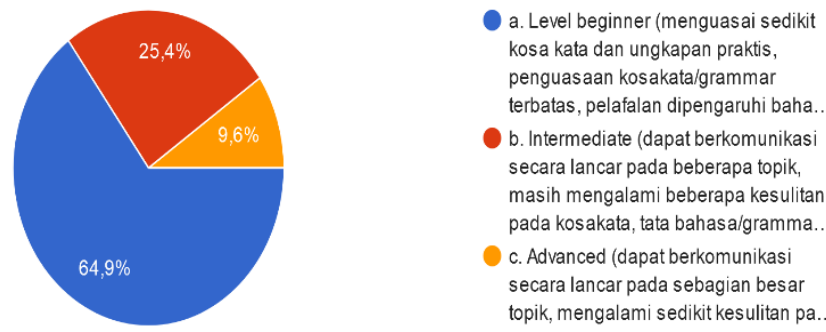

a. Level beginner (menguasai sedikit kosa kata dan ungkapan praktis, penguasaan kosakata/grammar terbatas, pelafalan dipengaruhi baha

b. Intermediate (dapat berkomunikasi secara lancar pada beberapa topik, masih mengalami beberapa kesulitan pada kosakata, tata bahasa/gramma. c. Advanced (dapat berkomunikasi secara lancar pada sebagian besar topik, mengalami sedikit kesulitan pa.

The data above might be used as the reference that the materials, activities, and teaching method that will be designed and used in English online teaching during pandemic should be fit to the students' 
ability. The table 1 below shows the students ability in reading and writing several kinds of English text.

Table 1. The Students Ability in Reading and Writing Several Kinds of English Text

\begin{tabular}{llll}
\hline No. Item & $\begin{array}{c}\text { Percentage } \\
\text { (reading) }\end{array}$ & $\begin{array}{c}\text { Percentage } \\
\text { (writing) }\end{array}$ \\
\hline
\end{tabular}

The students' ability

in reading and

writing to the

following text types.

$\begin{array}{lll}\text { a. Narrative } & 80 \% & 71 \% \\ \text { b. Exposition } & 69 \% & 63 \% \\ \text { c. Descriptive } & 79 \% & 75 \% \\ \text { d. Factual report } & 56 \% & 54 \% \\ \text { e. Procedure } & 73 \% & 70 \% \\ \text { f. News } & 78 \% & 63 \% \\ \text { g. Advertisement } & 80 \% & 68 \% \\ \text { h. Invitation } & 82 \% & 68 \% \\ \text { i. Announcement } & 77 \% & 77 \% \\ \text { j. Personal letter } & 70 \% & 68 \% \\ \text { k. Formal letter } & 63 \% & 55 \% \\ \text { l. Others (mention) } & & \end{array}$

Moreover the students ability in listening was showed that $83 \%$ of the students were good in practicing and improving their listening skill through listening a dialogue audio and they also claimed that they were good in practicing a dialogue $(82 \%)$ to improve their speaking skill. However, there are some difficulties that might occur and face in learning English which related to the four skills especially for the students in the beginner level. Based on the analysis result, the data showed that $41.4 \%$ of the students have the problem to speak grammatically correct, $35.3 \%$ of the students are lack in pronouncing the words and $22,4 \%$ of the students have limited vocabulary that might affect their speaking skill. They also stated that unsupported environment to use the target language in their daily life caused them less interested to speak English.

They also face some difficulties in listening which was showed in the data
$87.9 \%$ of the students get hitch to determine the meaning of the words or sentences they listen. While $11.2 \%$ of the students have restricted vocabulary mastery to understand what the speakers said. Related to reading and writing skills, the students also get some obstacles. The data is described at the following table 2

\section{Table 2. Student Obstacles}

\begin{tabular}{ccc}
\hline \multicolumn{1}{c}{ Item } & Percentage \\
\hline The difficulty of the students in \\
reading. \\
a. Limited vocabulary mastery & $39.7 \%$ \\
b. Limited grammar mastery & $19.8 \%$ \\
c. Limited knowledge of & $25 \%$ \\
& $0 \%$ \\
d. English texts & \\
\hline The difficulty of the students in \\
writing. \\
a. Limited vocabulary mastery \\
b. Limited grammar mastery \\
c. Limited knowledge of \\
$\begin{array}{l}\text { English text } \\
\text { d. Difficulty in organizing } \\
\text { content of the text. }\end{array}$ \\
e. Others (mention) ... \\
\hline
\end{tabular}

The data above describes students' difficulty both in reading and writing due to their limited vocabulary mastery whereas vocabulary is one of the essential elements both in comprehending the text and organizing the sentences during writing processes. In writing skill, they also have limited knowledge in organizing the content of the text.

Furthermore, in regard to what the students' wants for effective online English learning, it is crucial to consider the technology being used in online class. Carnevale (2009) argues that the more simple the technology is for the user, the better it is. Therefore, by considering the applicative technology will give great advantages both students and teacher The first application they preferred to use for online learning was Google Classroom (72\%), the second was 
WhatsApp (18\%), and Zoom (10\%). They also added that the use of Instagram and YouTube also can be applied as the media to share or submit the assignment given. While for speaking skill, the students believe to have rich vocabulary mastery $(45 \%)$ in order to speak fluently and have good spelling (32\%) and pronouncing the words followed by having good grammatically structure $(23 \%)$ in speaking could increase their speaking skill. Then for reading skill they wanted to learn the strategies for being good reader such as skimming, scanning, making inference, etc, (53\%) in English and preferred to master vocabulary (50\%) as they way to comprehend the meaning delivered in the text and followed by having good spelling (7\%). In addition, for writing and listening skills the students wanted to enrich their vocabulary (72\%) as the way to have good writing and could listen and comprehend what the speaker said well. They also wanted to learn how to organize the sentences to become a good paragraph (28\%). For listening they also preferred to learn spelling and pronunciation (28\%).

Moreover, for vocabulary mastery the students stated to learn. The data show that the students preferred to learn antonym (63\%), synonym (70\%), word types $(65 \%)$, and words definition (53\%). In learning grammar, the students agreed to learn all the topic or material that will be taught in grammar class and they also added to learn the function of grammar in a sentence and the best way to understand grammar.

Moreover, regarding to the learning input for English online learning, for listening skill the students preferred to learn simple monolog or dialogue using video which is uploaded in learning application $(46.6 \%)$, while $37.9 \%$ of the students wanted to learn useful expression through the audio and followed by $14.7 \%$ of the students who wanted to learn listening by using texts with picture through learning application. The duration for listening input they tended to have 30 minutes in listening the native speaker. While for reading input the data showed that the students interested to learn useful expression (56.9\%) and simple dialogue from short video or audio (44.8\%). For reading input the students wanted to read authentic reading material related to daily life (69\%), then simple reading texts (25.9), they also preferred to read a text which provided with difficult words (43.1\%).

Furthermore, after analyzing the target needs the next analysis is investigating the learning needs such as learning activities and teachers' roles during online English learning. Referring to the listening activities, the students wanted to discuss the content of monologue or dialogue $(60.3 \%)$, identifying people, time, and several topics given (50.8\%), and completing spoken response from the audio given (55.2\%). For speaking activities the students chose various activities to increase their skill such as practicing their speaking skill by having monologue or dialogue based on the picture, topic, given which is made in the form of video $(62.9 \%)$, having conversation in pairs using WhatsApp video call (48.3\%), exchange information with classmates by recording in voice note (38.8\%) and having self-presentation through video $(28.4 \%)$

Regarding to writing activities, the highest choice was arranging jumble sentences into a good paragraph (66.4\%), then writing an essay based on the topic they like $(55.6 \%)$, and writing a story based on the picture given $(50.2 \%)$. While for reading activities they preferred to read a text given and then retell what they have read in the form of video (55.1\%), analyzing the meaning of the words based on the context $(40.3 \%)$ and they also wanted to read a text 
then answer the question given (44.2\%). in order to know their pronunciation ability in reading, the students also wanted to read a text loudly and correctly through Zoom application as the way to increase their confident (32\%).

Moreover to increase the students vocabulary mastery easily, they preferred to learn by matching the words with provided correct synonym $(44,3 \%)$, finding the meaning based on the context, matching the words with the picture $(45.3 \%)$, playing vocabulary android games and sharing the score with classmates (68.2\%) and matching the word with definition given (33.3\%). While for grammar activities the students tended to listen to the lecturer' explanation first before doing the exercise $(83 \%)$, they also wanted to learn by identifying grammatical error in sentences $(55.2 \%)$, and writing the sentences using correct grammar they have learned $(50.1 \%)$.

Besides, the learner and teachers' roles are also being asked in order to get information about what the students wanted and needs during online class. Based on the result of investigation, the data showed that the students preferred to have many practices in English such as speaking which is made in the form of video and do all the instructions given in writing, reading, and listening. Additionally, the teachers' roles during online teaching is also essential as Gudea (2008) states that instructors are liable for stimulating the students' appreciation for the topic and for instructing and controlling them in mastering the subject given. While for teachers' role they wanted the teachers to give explanation before doing the exercise via Zoom and voice note/ voice recording, giving an example before having speaking or writing practice and giving feedback after submitting the assignment given.

\subsection{Discussion of Students' Needs Investigation}

The result of the students' needs analysis in the term of target needs revealed that the majority of the students wanted to have effective online teaching by using Zoom and voice note or short video as tools and media for the teachers in giving instruction or explanation about the subject. While Google classroom might be used as the tool to share and submit the assignment. In order to have good interaction and ease the students who live in restricted internet access, WhatsApp is one of the best applications to be used during online class. As Klobas, \& Renzi (2009) state that technology should support better interaction and students participation in an interactive format. So, anything that would make it transparent, and would help the learner in online class. The students also wanted numerous activities for promoting the four skills of English by having appropriate learning input for them who mostly still in the beginner level.

In addition, related to the learning needs the activities that might engage the students to be active during online class, having students to make creative video and recording their voice to practice their speaking skill would be great choice and by utilizing the social media such as Instagram or Facebook also might promote their writing skill. The students also expected the teachers role such as giving feedback for every assignment they had accomplished and could give explanation for difficult topic being learned.

\section{CONCLUSION}

The continuity of education during Coronavirus could be conducted through online teaching. As the way to have success in teaching online both the teachers and 
students should have appropriate and convenient work environment. The teachers have to consider the obstacles that the students face such as limited internet access they have in their area so that ideally both students and teacher should have adequate internet data package to have good access in utilizing supported technology during learning and teaching English. Numerous learning material activities could be applied during English online class by considering students language proficiency.

The finding of this research described all the students needs for effective English online learning and could be the references for the teacher in preparing appropriate learning material, technology, and activities during online class.

\section{REFERENCES}

Carnevale, D. (2010). Learning online to teach online. Chronicle of Higher Education, 50(10).

Gudea, S. (2010). Expectation and Demand in Online Teaching, Practical Experience. Information Science Publishing; New York.

Klobas, J., \& Renzi, S. (2003). Integrating Online Educational Activities in Traditional Courses: University-Wide Lessons After Three Years. In A. K. Aggarwal (Ed.),Web-Based Education: Learning From Experience (pp. 415439). Hershey, PA:Information Science Publishing.

Joshua S. (2020) Introduction to Online Teaching and Learning. Retrieved on June 20, $2020 \quad$ from http://www.wlac.edu/online/documents/o tl.pd
Jena, K., P. (2020). Online Learning During Lockdown Period for COVID-19 in India. International Journal of Multidisciplinary Educational Research, VOL 9, ISSUE 5(8)

Nation, I. S., \& Macalister, J. (2010). Language Curriculum Design. New York: Routledge.

Bosher, S., \& Smalkoski, K. (2012). From Needs Analysis to Curriculum Development: Designing a Course in Healthcare Communication for Immigrant Students in the USA. English for Specific Purposes, 21, 59-79. 